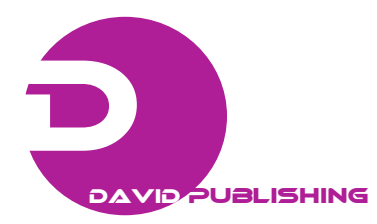

\title{
Camel Milk: Disease Control and Dietary Laws
}

\author{
Avi Levy ${ }^{1}$, Lillian Steiner ${ }^{1}$ and Reuven Yagil $^{2}$ \\ 1. Hemdat Hadarom, Religious Academic College for Education, Jewishness and Science, Netivot 80200, Israel \\ 2. Department of Physiology, Faculty of Health Sciences, Ben-Gurion University of the Negev, Beersheva 84231, Israel
}

Received: August 17, 2013/ Accepted: October 04, 2013 / Published: December 31, 2013.

\begin{abstract}
Although there is a large increase in interest in camel milk as a comparative medicine, there is no accompanying knowledge of camel milk in general, so no specific health laws or knowledge of its use with dietary-laws is available. For the reason, doctors are reluctant to advise using it, although more and more evidence appears about its positive effects. Camels are not ruminants but do ruminate. They are tylopodes. The health laws are based on those for cows so often all positive components are destroyed. As Jewish laws are based on scientific evidence and requirements for the animals camel milk is rarely suggested to be of use. This publication deals with all three points (data about camel milk, health and dietary laws) for bringing camel milk to the notice of the authorities, scientists and practitioners. It also provides suggestions for the health and religious authorities. This publication has data of the special properties of camel milk and examples of diseases that respond to drinking it. The health laws demand pasteurization of the camel milk but this detracts from its efficacy. An alternative is presented—-"pathogen-free” camel milk, providing a safe and effective commodity.
\end{abstract}

Key words: Protective proteins, dietary laws, pasteurization, comparative medicine, autoimmune, tylopodes.

\section{Introduction}

Increased cow milk production and supply has seen milk prices go down significantly all over the world, except for camel milk, which accelerated significantly [1]. The FAO estimate a yearly income of $\$ 10$ million per year [2]. The use of camel (C. dromedarius) milk as a CAM (Comparative Alternative Medicine) is undergoing a world-wide upsurge. This is mainly due to the data that explain what are the milk components which exert the medical benefits [3, 4]. The upsurge of camel milk has not been accompanied by physicians having more knowledge and so have little experience with camel milk. In addition, the medical requirements for marketing are assumed to be the same as for cow milk although there are great differences between the animals and hence, their milk. This has led to no clinical trials been carried out.

The aim is that the medical practitioners will be

Corresponding author: Reuven Yagil, professor, research field: camel milk and autism. E-mail: reuven@bgu.ac.il. familiar with camel milk and confront the medical laws governing its use, including the dietary laws, which need a knowledge of both diseases and camel milk.

\section{Knowledge of Camels and Camel Milk}

Camelids are even-toed ungulates: They are classified in the Order Artiodactyla, along with deer, giraffes, cattle and goats [5]. Camels were first domesticated for their milk [6] and remained as a food for the nomadic peoples in the world up until today.

Use of camel milk for treating diseases is not new but is mentioned in the Surah (Khan, 1974) [7] and in a book comparing the Koran, Talmud and New Testament that was published by Dr. Weill in New York in 1864 [8].

However, for many years camels were relegated to “primitive, nomadic” tribes in Third World countries. RY (author) published a book on the special adaptive mechanisms of the one-humped camel [9], including a chapter on lactation and a publication for the FAO on 
“camels and camel milk" [10]. He also organized two international conferences focusing with the productivity of camels-one in Eilatin 1996 and the other in Almaty, Kazahstan in 2000 m, before the FAO concluded that it is economically lucrative [2].

\subsection{Origins of Camelids}

The camel family originated in Northern America when the land masses were still joined [12]. After migrating they eventually survived in the harshest environments in the world: the llama, alpaca and guanaco in the heights of the Andes, the two-humped Bactrian camel in the Gobi desert of China and Mongolia and the one-humped dromedary in the extremely hot and arid deserts in Africa and Middle East. Therefore, camels are not exotic animals but indigenous ones in Northern America.

\subsection{Efficacy of Camel Milk as Cam}

Many auto-immune diseases have reached epidemic levels in industrialized countries, with a constant search for therapies. Allergies and other immune maladies are also wide-spread. There is often a dubious acceptance of the etiology of these diseases by the medical practitioners [4].

Contrary to the human immune system, which can not pass thick tissues in the body, it has been proven scientifically that the camel immune system has very small, active antibodies, nanobodies [13, 14]. These antibodies are secreted in the milk throughout lactation in the camels [15]. The camel antibodies are so special that the USA department of Homeland Security use them to create biosensors to find which organic substance will be used in a future biological warfare attack [16].

\subsection{Components of Camel Milk}

Fat: Camel milk consists of $2 \%$ fat which are mainly polyunsaturated fatty acids, omegas. These fats are completely homogenized so appear as minute globules in the milk, giving it the white color.
Lactose (milk sugar) is readily digested by human lactase with no signs of "lactose intolerance".

Proteins: Camel milk does not contain the allergens which are present in ruminant milk. Insulin is one of the camel milk proteins and as camel milk does not form cheese the milk quickly passes the stomach into the intestines. Therefore, insulin is not destroyed and is absorbed into the blood where it reduces blood sugar [17]. Camel milk contains a number of "protective proteins" which keep the body healthy. They consist of strong antibacterial, antiviral and antifungal substances and the immunoglobulins [18]. Among the "protective proteins" in camel milk is lactoferrin which was examined for its ability to inhibit the proliferation of colon cancer in vitro, and repair of DNA damage [19]. This explains the healing of stomach and colon cancers observed in a number of cases (personal observation).

There are also tissue repair substances among the protein protectors.

Vitamins and electrolytes: The most important vitamin is vitamin $C$ and calcium and iron are the most important electrolytes. The need for duodenal acid for calcium absorption in cases of osteoporosis is satisfied by camel milk rapidly passing the stomach, with the acid that is constantly being secreted and the vitamin $\mathrm{C}$ (ascorbic acid) increasing the amount of calcium absorbed and deposited in the bones [20].

Taking the special properties of camel milk into account, the following positive observations can be explained.

Children not ingesting food: There are cases when young infants can not ingest any food after their mothers' milk slowly declines, including use of the milk substitutes. There are special solutions and commercial milk-alternatives but they, as well as the substitutes, do not help the development of the immune system. Therefore, these children suffer from many diseases. Camel milk is readily imbibed.

Camel milk has a good nutritional composition, being close to mothers' milk and importantly, has the 
many protective proteins, especially the immunoglobulins. Infants who get the camel milk have far less illnesses than their counterparts.

Allergies [21]: Many children, and adults, suffer from food allergies. As camel milk does not contain allergens and the immune system is rehabilitated, children recover from their allergies.

DM (Diabetes mellitus): There are three types of diabetes: Insulin dependent IDDM; Insulin independent IIDM and GDM (gestational diabetes). They are autoimmune diseases. The IDDM and GDM require insulin treatment. Camel milk contains insulin, which has been shown to be beneficial, also in animal studies [17]. The IIDM is caused by a malfunction of the receptors for insulin on the cell surface. As camel milk contains tissue repairing proteins, the problem is cured.

Autism: Autism is an autoimmune disease which does not affect the brain but rather the intestines [22]. The physiological breakdown of two cow milk proteins (caseins)-casein and lactoglobulin-to amino-acids is abnormal, forming a powerful opioid, casomorphin. If the formation of the opioid that cause the brain symptoms but if continued for years will eventually cause permanent brain damage, creating a window of opportunity to cure autism at an early age. Because cow milk caseins produce enough opioid to completely remove cow milk and its products from the diet to alleviate the symptoms. The symptoms are then removed but the children are still ill.

Camel milk does not contain the two caseins responsible for the formation of the opioid and rehabilitates the immune system, so-doing curing the autism.

Crohn's Disease [23]: Scientific evidence indicates that it is NOT primarily an autoimmune disease but rather a bacterial infection caused by Johne's Disease in cows, the bacteria being MAP (Mycobacterium avium paratuberculosis). The symptoms of these cows are identical to those of persons with Crohn's Disease. It has been established that MAP passes into cow milk and is not destroyed by pasteurization. The MAP then enters the intestinal tissue as a saprophyte, not creating any symptoms. A very severe emotional stress activates the MAP and it becomes active in the intestinal tissue. The reaction of the body is to send antibodies to the intestines but as they can not pass into the thick tissue they "attack" the intestines themselves, creating an autoimmune disease.

Camel milk “protective proteins" pass into the intestinal tissue, destroying the MAP and rehabilitating the immune system. This was presented in 2012 in a scientific meeting of USA gastroenterologists [24] following which clinical trials with camel milk are being initiated in New Jersey with a prominent gastroenterologist.

Hepatitis: Hepatitis is a world-wide affliction, often requiring inoculations against it. Scientific publications have shown that camel milk cures both hepatitis B and hepatitis $\mathrm{C}$. The special fat in camel milk also soothes the liver [25].

Tumors: There are a number of tumors which can be cured with camel milk, the action is due to the fact that the very active antibodies bind onto the tumors, killing the tumor calls without damaging healthy tissue. Human antibodies are too big to do this [13]. Lactoferrin also is effective in some cancers [19].

\section{Health Requirements}

The health laws usually demand pasteurization of milk, whatever its origins, eradicating pathogen bacteria while knowingly destroying benefits in inherent in raw milk.

The FDA and national milk control boards all have requirements for camel milk based on those for cow milk, notwithstanding that every aspect of camel milk is different to those for cow milk (Yagil). The first and foremost health law for milk is pasteurization. Pasteurization kills all bacteria, making no differentiation between "good” or "bad” bacteria. Ass and mare milk are not pasteurized but camel milk must undergo pasteurization in all countries where it 
is used.

As many of the CAM benefits of camel milk are due to bacteria it is clear that pasteurization is not beneficial. As camel milk has powerful antibacterial properties it has been found that it can be checked for pathogens and when found "pathogen free" is fit for use. The laboratory must be an official one and the costs borne by the marketer of the camel milk. Therefore, for camel milk it is possible to market pathogen-free milk, similar to that of Danone's "Actimel”.

\section{Dietary Laws}

Dietary laws, pertaining to milk are strict for Jewish consumers [11]. For instance meat can be eaten and milk drunk but not meat and milk together. A "good” milk product can only come from animals with split hooves and ruminate. Mothers do not have split hooves or ruminate but breast feeding is allowed, under certain circumstances.

Camel has split hooves and ruminate, although not ruminants but tylopodes [5], but still is a suspect food. For use of camel milk for medical purposes there is no "one-law" but permission must be given by the person's personal rabbi. One of the questions the Rabbis ask is "is there scientific evidence that the camel milk will, indeed, be beneficial?”. This paper suggests an answer to this question.

The answer to the dietary laws will also be valid for Muslims and for persons, or doctors, deciding whether camel milk should be drunk or not.

This article is not meant to give Rabbis, Muslims and persons interested in imbibing camel milk information about the dietary laws but rather to provide scientific data explaining the comparative medicinal properties of camel milk and how the laws pertain to drinking it.

Four main parameters can influence the final ruling by a Rabbi whether camel milk can be drunk.

"Is there another successful treatment?"

If there is another proven treatment then camel milk is not advised.

"Is the treatment with camel milk known definitively?" Has it been tested and proven scientifically, as demanded by the halacha? Or could the experience accumulated over the years and supported by certain scientists suffice?

There is scientific proof showing the medicinal benefits of camel milk over thousands of years. What has held up clinical trials has been the demand for pasteurization of the milk. There is now the possibility of providing pathogen-free-camel milk so clinical trials are beginning. Also, camel milk can be considered as Comparative Alternative Medicine, making clinical trials optional.

It is scientifically clear that camel milk can alleviate osteoporosis in women. The question is whether this is a life-threatening condition or not or does the "quality of life" suffice to allow camel milk consumption?

"Is a known treatment free of side-effects which could affect the future health of the person?"

An example is gestational diabetes where the treatment of choice is insulin injections. This can put the mother in future risk of persistent diabetes, which could lead to her death and negatively affect the future health of the child. Camel milk prevents these side effects.

Another example is camel milk can prevent the side effects of chemotherapy and radiation, making the treatment more effective and prevent the treatment becoming a medical problem.

"Should the taste of the camel milk be changed?" It is commonly suggested that the taste of camel milk should be altered to make it taste bad, so as not to enjoy it.

However, as the camel milk is being drunk as a treatment and not for enjoyment any additions to the milk must not negatively affect the milk but, more importantly, not be a hazard to the person. By adding large amounts of salt it can have negative effects as well as making a person, especially a child, reluctant 
to drink the milk. The camel milk will only be given as long as the malady persists, then can be ceased.

As large volumes must be taken, it is impossible to put the milk into capsules. Anesthetizing the mouth and throat is not a viable alternative. Nor is the daily use of a tube to pass the base of the tongue.

The same points of reference for the Jewish dietary laws are valid for Muslims and persons evaluating the use of camel milk CAM.

Given these promising and amazing data, the camel milk was used as a healing substance. CAM, must be taken into account and discussed according to the laws in order to advise its use.

\section{Conclusions}

Comparative medicinal treatment of diseases is presented together solutions to health and dietary law restrictions. A religious person wanting to use camel milk to treat a disease must consult his/her Rabbi. The main points which will determine whether a Rabbi can agree to a person drinking camel milk are pertinent for physicians as well as those interested in learning about the efficacy of camel milk.

Is there an effective treatment? If so, then drinking camel milk is contraindicated.

If there is an effective treatment to gestational diabetes with some bad side-effects, then camel milk can be drunk. The conventional treatment is injections with insulin that can leave the mother with persistent diabetes and the fetus with damage to his/her pancreas.

If there is no effective treatment then it is advisable or even compulsory to drink the camel milk. This is true for many of the autoimmune diseases.

\section{References}

[1] The International Energy Agency (IEA) [Online], http://reliefweb.int/sites/reliefweb.int/files/resources/Mar ket-data-update (accessed April 30, 2013).

[2] FAO Bulletin, Camel's milk could hit UK shelves, BBC News, April 21, 2006, [Online], http://news.bbc.co.uk/2/hi/health/4930094.stm (accessed
April 30, 2013).

[3] R. Yagil, Camel milk and its unique anti-diarrheal properties, Editorial. IMAJ 15 (2013) 35-36.

[4] R. Yagil, Comparative Alternative Medicinal (CAM) Properties in Camel Milk for Treatment of Epidemic Diseases, Journal of Agricultural Science and Technology 3 (2013) 575-580.

[5] Tylopodes Available [Online], http://en.wikipedia.org/wiki/Camelid (accessed June 6, 2013).

[6] H. Epstein, The Origin of Domestic Animals of Africa, Africana Publishing Corporation, New York, 1971.

[7] M.M. Khan, Sahih al-Bukhari, The translation of the Meanings of the Koran, Saudi Arabia, Al-Medina Islamic University, Saudi Arabia,1974.

[8] G. Weil, The Camel in: Noah, Hud, and Alih, Comparison between the Bible, the Koran and the Talmud, New York, 1864.

[9] R. Yagil, The Desert Camel: Comparative Physiology, Comparative Animal Nutrition, S. Karger AG., Basel, Switzerland, 1985.

[10] R. Yagil, Camels and Camel Milk, FAO (Food and Agricultural Organization of the UN), 1982.

[11] Dietary Laws [Online], http://www.jewishvirtuallibrary.org/jsource/Judaism/kash rut.ht (accessed June 5, 2013).

[12] Evolution camelids Available [Online]: http://en.wikipedia.org/wiki/Camelid (accessed June 6, 2013).

[13] R. Hamers, Immunology of camels and llamas, in: P.P. Pastoret, P. Griebel, A. Gaevarts (Eds.), Handbook of Veterinary Immunology, Academic Press, New York, 1998, pp. 421-437.

[14] S. Muyldermans, C. Cambilla, L. Wyns, Recognition of antigens by single domain antibody fractions: the superfluous luxury of paired domains, Trends in Biochem, Sci. 26 (2001) 230-235.

[15] R. Yagil, Lactation in Camels, in: T.K. Gahlot (Ed.), Selected Topics on Camelids, The Camel Publishers, Bikaner, India, 2000, pp. 61-72.

[16] C.Q. Choi, Llamas (Camelid) Enlisted to Thwart Biological Weapons, Life Sciences Com., 2006.

[17] R. Yagil, O. Zagorski, C. van Creveld, A. Saran, Science and camels' milk production, in: P. Bonnett (Ed.), Dromedaries and Camels, Milking Animals, Mauritania, 1998, pp. 178-191.

[18] S. Kappeler, Compositional and structural analysis of camel milk proteins with emphasis on protective protein, Ph.D. Thesis, Eidgenössische Techische Hochschule Zürich, Switzerland, 1998.

[19] H.M. Hosam, I.H. Wissam, R. Schneider-Stock, H.M. 
Hassan, Camel milk lactoferrin reduces the proliferation of colorectal cancer cells and exerts antioxidant and DNA damage inhibitory activities, Food Chemistry 141 (2013) 148-152.

[20] Calcium metabolism Available [Online], http://www.lumrix.net/medical/physiology/calcium_meta bolism.html (accessed June 6, 2013).

[21] Y. Shabo, R. Barzel, M. Margoulis, R. Yagil, Camel milk and allergies in children, IMAJ 7 (2005) 796-798.

[22] Y. Shabo, R. Yagil, Etiology of autism and camel milk as therapy, International Journal on Disability and Human
Development 4(2) (2005) 67-70.

[23] Y. Shabo, R. Barzel, R.Yagil, Etiology of Crohn's disease and camel milk treatments, J. Camel Practice \& Res. 15 (2008) 55-59.

[24] D.M. Rosenheck, Y. Ravee, R. Yagil, Camel milk as an alternative medicine for Crohn's Disease, in: ACG (American gastroenterologists) annual scientific meeting \& postgraduate course, Las Vegas, 2012.

[25] H. Saltanat, The influences of camel milk on the immune response of chronic hepatitis $\mathrm{B}$ patients, Chinese $\mathrm{J}$. Cellular Mol. Immunol 25 (2009) 431-433. 